\title{
TYPE AND MEANING OF THE FIGURATIVE LANGUAGE FOUND IN NIKI'S SELECTED SONGS' LYRICS
}

\author{
Wenny Alfiyani \\ Faculty of Language and Arts Education, University Of PGRI Semarang \\ Email: wennyalfiyani4@gmail.com
}

\begin{abstract}
Alfiyani, Wenny. 2021. Type and Meaning the Figurative Language Found in Niki's Selected Songs' Lyrics. Final project English Study Program, Faculty of Language and Arts Educations, University of PGRI Semarang.

This final project is based on the study, which attempted to the analysis of the Figurative language in Niki's selected songs. The three songs were Lose, Indigo, and La La Lost You. The main purpose of this study was to found the types, the dominations, and the meaning of figurative languages used in the songs, and the contribution to teach poetry. This study expected to be a source for the English teachers to teach Poetry. This study is qualitative research, which analyzed the types and meaning of the figurative language found in Niki's songs lyrics using Kennedy, X.J. and Gioia. D. 's theory (2005). The data of the research collected by listening, watching, reading, identifying, analyzing, and classifying.

The result of the study was there were seven types of figurative language found in the study. In addition, they were metaphor, hyperbole, repetition, simile, apostrophe, paradox, and allegory. The contributions to teaching poetry was could make a positive and full attention learning, Improving memory, also enhance their imagination.
\end{abstract}

Keywords: figurative language, song lyrics, niki-nicole zefanya, poetry teaching

\section{Introduction}

Background of the Study

The song is the broadest thing that people around the world know for a long time. The most basic explanation about the song is a combination of music and words or song lyrics. As an important part of a song, most of the song lyrics wrote by using figurative language, because when the songwriters write song lyrics using figurative language makes the meaning from the song lyrics more colorful and more interesting for the audience. Their uniqueness in each creation adds so many certain meanings and effects to create their work more imaginative and interesting by adding figurative language to their song lyrics. 
Niki is one of the singers and songwriter that use figurative language. Her song is very interesting and easy to listen to and can be use as a medium to learn figurative language because it uses figurative language quite a lot. Niki has her uniqueness and characteristics; she often plays with the words in the lyrics of the songs using figurative language and repetition as Niki's characteristics in singing. As she said in her interview with genus on YouTube the way she said she loved it when playing with words she feels like a musical genius, and when a syllable meets a syllable it will produce something very impressive. In other words, Niki arranges the words she uses neatly, making a song that has catchy and meaningful lyrics.

Niki Zefanya or with her stage name Niki writing her song lyrics to be a place to express her feelings, as a means of communication to convey her feelings to other people. Most of her songs based on her experiences, expressing how she felt at that time, how she described someone, an event, or anything in a song lyric and she packaged it very uniquely according to the type of music he used to bring.

Not only that, Niki has a fairly clear English pronunciation even though the lyrics are fast, so when she sings the meaning of the song is conveyed well. Especially for the top three songs that contain so much information of figurative language and also unique words. So this can be a perfect example to understand figurative language.

According to Kennedy and Gioia (2005: 118), said that 'comparatively' is the figure of speech. Meanwhile, Bradford T. Stull (1961), said that figurative language is when people speak symbolically about the subject. From those, we can aw a line that figurative language created by showing different words or using symbols to compare and to describe something.

As said before, figurative language is using different words or using a symbol, in other words, figurative language cannot interpreted directly based on the words displayed in a literary work, because the unique from figurative language, so people must read or heard it carefully to understand well what the meaning is to convey.

Based on the description above, the writer interested conducted a study entitled "Type and Meaning the Figurative Language Found in Niki Zefanya's Selected Songs' Lyrics and Its Contribution to Teaching Poetry".

Purpose of the Study

To analyze what type of figurative language in Niki's selected songs' lyrics.

To find out the dominant figurative language found Niki's selected songs' lyrics. 


\section{Type and Meaning of the Figurative Language Found in Niki's Selected Songs' Lyrics (Wenny Alfiyani)}

To find out the figurative language meaning in Niki's selected songs' lyrics.

To find the contribution of this study to teaching poetry.

\section{Theoretical Framework}

Review of Related Theory

1. Figurative Language

Figurative language is like a comparative definition. Figurative language can give a fresher impression and unusual emphasis on the denotation of regular words (Kennedy and Gioia 2005: 118).

Besides, Carla Swerman (2013), also describes that figurative language is explained in detail or reveal something difficult to explain in literary language It does not matter if it is not factually true, figurative language helps the writer to re-create, and makes the reader can feel more of an experience. For the songwriter and poet, figurative language is not only used to explain something that is not true, and most of them use figurative language to attract more attention to such truth in their works, that is why figurative language is the common language to use in their work

Figurative language is related to the use of figures of speech and language cannot be taken literally, and it is used to express what the writer or speaker wants to convey. To analyze the type of figurative language used, here are some types of figurative language:

a. Simile

According to Kennedy and Gioia (2005: 121), the "simile is a figurative language that expresses a similarity of an object, but something that is compared is not an object of the same type". Simile reached when two things are not merely compared but the emphasis is added by stating that one transcends the other in intensity. The characteristic of simile is the use of the words 'like' and 'as' when comparing them. A simile related to poetry because in general similes often appear exclusively in the writing of poetry.

His eyes were shining like stars.

Dewi's skin white as a cloud in the sky.

b. Metaphor

According to Kennedy and Gioia (2005: 121), metaphor is the result of the simile is a statement of one thing but in something else, not the literal sense. Metaphor uses the 'specific 
word. Unlike a simile, a metaphor compares things without using the word 'like' 'as' 'tubs' and so 'on', metaphor uses the words like is, are, was, or were when compare or the two things. Metaphore is an imaginative way of describing a person, object, or idea by referring to something else that you think has similar qualities to the person, object, or idea you are trying to describe, example:

Sea of sadness.

Shownu is a bear when he eating.

c. Personification

Personification is a "figure of speech for a thing, animal, or abstract terms like truth or nature is made a human." (Kennedy and Gioia: 2005). In other words like humans, we humanize or give life to any difference or give human-like characters to random objects or others. For Example:

The grasses dance with the wind.

The sky cried with me today.

d. Irony

"Irony is when someone says one thing but with the opposite meaning or meaning, where insults are subtly conveyed beneath the surface of the language" (Kennedy and Gioia 2005: 35). The irony is used to state a contradiction, hide the facts, or contradict the facts. For example, declare the opposite meaning with the true meaning and the mismatch between the atmosphere presented and the reality that underlies it.

Goddamn, that was terrible.

How great your idea.

How great your idea it has the opposite meaning which is said when someone does not want to hear or does not want to use the idea.

e. Synecdoche

According to Kennedy and Gioia (2005: 186), "synecdoche is the use of a significant part of an object to describe the whole object or Vice Versa. For examples:

You need to try various kinds of wheels.

The word wheels in the sentence above stand for vehicles.

f. Apostrophe

Kennedy and Gioia (2005: 129) stated, "Apostrophe is a figure of speech where a person or something that exists or does not exist is considered to be there. In the apostrophe literature, it is often presented with the exclamation "O", for example: 


\section{Type and Meaning of the Figurative Language Found in Niki's Selected Songs' Lyrics (Wenny Alfiyani)}

"Welcome, O life! I go to encounter for the millionth time the reality of experience and to forge in the smithy of my soul the uncreated conscience of my race." (James Joyce, a Portrait of the Artist as a Young Man).

g. Allegory

"Allegory is where principles and ideas are explained in the form of characters, events, and figures" (Kennedy and Gioia 2005). Example:

Like a spinning wheel, life is sometimes above, sometimes below.

In other word, allegory is when explaining something, not in literal, but using symbols or part of things to explain something else and represent it as a whole storyline.

h. Paradox

According to Kennedy and Gioia $(2005 ; 121)$, a paradox occurs in a statement that at first strikes us as self-contradictory but then on reflection makes some sense. The paradox is a style of language that says something opposite or contrary. Examples:

Honesty in a trial is a lie if there is no evidence.

The people's representatives heard, but pretended to be deaf.

The sentence The people's representatives heard, but pretended to be deaf, the sentence describes two different things at the same time, heard and deaf.

i. Repetition

Repetition is a repetition figure where the repetition of the word serves to convey the meaning that is in the word or series of words. It is not only for entertaining repetition is also used when songwriters and poets want to give it to a certain part to convey meaning properly. He will try to study, study, and study to achieve his dreams

j. Hyperbole

According to Kennedy and Gioia (2005: 129), Hyperbole or overstatement is not a literal truth but using a figure of speech when speaking about something, here are some examples: He ate an amount of rice at a time.

She has a million things to do, she cants join us.

2. Song and Song Lyrics

According to Patel (2003), songs were written by composers or poets who are good at composing words. Everything in life such as hate, love, happiness, regret, sadness, nature, 
bad or good, can all be written into a song. Songwriters use this or write a song as a means to express their feelings and be able to present their lives.

The basic function of songs is as entertainment, many people use songs to improve their mood and other things like music. Many people think that music and songs are the same, but they are different. If music is a collection of sounds, while the song is a combination of music and words or song lyrics that are mutually continuous and sung by someone or in a group.

Lyrics are a collection of complimentary verses to a song can also be referred to as short non-narrative poems, which express personal thoughts, feelings or emotions, nowadays poems lyrics are very popular because of their quality, the quality of the lyrics, the rhythm is pleasant to hear and the harmony when accompanied by music.

According to Virginia Jackson and Yopie Prins (2014: 49), the lyric was always related to erlebnis, or the lived experience of a person or the author self, this is like the idea that came out in the nineteenth century which states that a lyric is written by imitating the feeling. Lyrics are personal things but are shown to readers or listeners to know the secret of the lyrics of the poems.

Lyric demonstrates certain feelings or feelings of a poet through words, so some think that lyrics are personal or the secret of someone, various kinds of emotions are shown from extreme to unclear what purpose is conveyed, about a life, bitter-sweet, sad, the death of love or hatred.

\section{Niki - Nicole Zefanya}

Has Indonesian blood Nicole Zefanya or usually called Niki as her stage name, was born on January 24, 1999. With the R \& B music, she brings to each of her songs; Niki has a unique and calm voice for the audience.

Not only a singer, but Niki is also a song lyricist, with her easy listening songs and also unique lyrics, Niki is becoming more famous with all of her works. For her music, she draws inspiration from the music she has listened to since childhood, including Destiny's Child, Aaliyah, Mariah Carey, Boyz 2 Men, and Alicia Keys.

Even though she was born and raised in Indonesia, she is familiar with English because Niki was educated at an international school and has an American accent. Niki is an Indonesian singer with an international career, joining the record label from United States 88rising, along with Rich Brian. 


\section{Type and Meaning of the Figurative Language Found in Niki's Selected Songs' Lyrics (Wenny Alfiyani)}

Niki started her career in 2014 by releasing a single entitled Begin the Day with Love under the auspices of Sony Music. And by joining 88Rising as her new agency, Her career exploded, with the title See You Never and I like you, which finally became her debut song under the auspices of 88rising on July 11th, 2017.

\section{Research Method}

This study was qualitative research. This was intended to make an accurate and systematic description related to the lyric, more precisely the figurative language used in the song lyrics in the song's chosen song from Indonesian singer Niki.

1. The writer visited the YouTube Channel by 88Rising and Niki Zefanya. In addition, watch some music videos and then choose the three songs.

2. Reading the song lyrics

After the writer chose the song from Niki's and 88Rising YouTube channel, the writer read the chosen song lyrics repeatedly one by one, to get more understanding about the song and the types of figurative language that used.

3. Identifying and analyzing the song

After chose the songs, the writer identified and classified sentences from those song lyrics that were included as figurative language, the writer classify the figurative language in detail based on its types. While described the figurative language that used, the writer also discussed the meaning from the lyric that contained figurative language.

4. Listing the figurative language

The next steps are to make a list of the song lyrics that conduct figurative language and the meaning from the song's lyrics.

5. Conclusion

After the various steps, the writer concluded the study. The conclusion was about the result of the song lyrics that analyzed, the types of figurative language that used, and the domination figurative language used by Niki on her song lyrics.

\section{Result and Discussion}

Research findings explain the identification of figurative language in Niki Zefanya's selected songs lyrics based on her top 3 songs on her YouTube channel, selected from the 
most viewers. The title is Lose, Indigo, and La La Lost You (acoustic version) those discussed as follows:

Result

1. The types of Figurative Language Found in Niki's Selected Songs' Lyrics

Table 4.1 Types of Figurative language Found in Niki's Selected Song

\begin{tabular}{|c|l|l|l|l|l|}
\hline \multirow{2}{*}{ No } & \multirow{2}{*}{ Types of Figurative } & \multicolumn{2}{|l|}{ Song Title } & \multirow{2}{*}{ Total } \\
\cline { 3 - 5 } & Language & Lose & Indigo & La La Lost You & \\
\hline 1. & Simile & 1 & 1 & 1 & 3 \\
\hline 2. & Metaphor & 2 & 7 & 9 & 18 \\
\hline 3. & Personification & - & - & - & - \\
\hline 4. & Irony & - & - & - & - \\
\hline 5. & Synecdoche & - & - & - & - \\
\hline 6. & Apostrophe & 1 & - & 2 & 3 \\
\hline 7. & Allegory & 1 & - & - & 2 \\
\hline 8. & Paradox & 1 & - & 1 & 5 \\
\hline 9. & Repetition & 1 & 3 & 1 & 9 \\
\hline 10. & Hyperbole & 4 & 5 & - & $\mathbf{4 1}$ \\
\hline Total & & & & 2 \\
\hline
\end{tabular}

Based on the table above, the writer found figurative languages were used in the three selected songs by Niki entitled Lose, Indigo, and La La Lost You by Niki, and the types of figurative language were simile, metaphor, apostrophe, allegory, paradox, repetition, and hyperbole. The writer did not found personification, irony, and synecdoche in the song.

2. The Dominant Figurative Language Is Found in Niki's Selected Songs' Lyrics

Based on the data above, from the songs entitled Lose, Indigo, and La La Lost You by Niki, the writer found that metaphor was the dominant figurative language from the 41 expressions. The writer found two expressions in the song Lose, seven expressions in the song Indigo, and nine expressions in the song La La Lost You with a total of 18 expressions that conduct figurative language metaphor. In her song, Niki very often uses figurative language metaphor to explain and compares something, a feeling or an object with other words that have the same characteristic, so that the meaning was well conveyed to the audience and more interesting. 


\section{Type and Meaning of the Figurative Language Found in Niki's Selected Songs' Lyrics (Wenny Alfiyani)}

Then, the writer found the next dominant figurative language in Niki's Songs Lyrics they are nine expressions that contain hyperbole, five expressions that contain repetition, 3 expressions that contain one figurative language simile, 3 expressions of figurative language apostrophe, two expressions contained figurative language paradox, and last one expression of figurative language allegory.

Discussion

1. The Meaning of The Figurative Language Is Found in Niki's Selected Songs' Lyrics

a. Metaphor

I don't need to take your heart (Song Lose, line 5)

You keep yours, I'll keep mine (Song Lose, line 6)

This lyric uses a figurative language metaphor. The meaning of the song lyrics is that Niki should not have to take the feelings of the man and have a relationship with him, take your heart is not taken literally a heart inside the body, but describes the feeling. And in these lyrics, she said that they should not be together from the beginning. Niki also did not want to hurt the man's heart and they should keep their feelings to each other.

b. Hyperbole

'Cause I ain't tryna be the one (Song Lose, line 3)

Been through this a thousand times (Song Lose, line 4)

The lyric contains figurative language hyperbole. It makes sense for Niki to say that she is the only person who struggles with the relationship. But it does not make sense for Niki to say that she has done as many things as a thousand times. It was normal when people were angry she said something exaggerated like the lyrics above. And that was how Niki felt; the lyrics have meant that she feels like she was the only person who does all kinds of things to maintain a relationship, thousand times over.

c. Repetition

So I'm goin' (Song Lose, line 38)

I'm gonna let you go, let you go (Song Lose, line 39)

In the lyric, there was figurative language repetition on the word let you go. By the repetition, Niki wanted to make it clear that she was better off letting the man left and not deal with him anymore.

d. Simile 
As far as the indica goes (Song Indigo, line 19)

In the lyrics, Niki uses the word 'as' to compare. Niki compared indigo in the previous lyrics with indica. Indica is a type of drug, and drugs are often illegally exported to faraway places. As far as the indica goes represented their pleasure was as long as the indica goes through the world. The lyrics have the meaning of enjoyment between the two of them as long as possible.

e. Apostrophe

Does the trick for all of the things left unsaid. I'm (Song La La Lost You, line 7)

Missin' our drunken 2 a.m. strolls in k-town (Song La La Lost You, line 7)

The meaning was quite clear, but here Niki was flashback to her memories and seems to be talking to her ex. Even Niki already moved on.

f. Paradox

Silverlake, Hollywood, pretty little white lies got me good (Song La La Lost You, line 25)

Thought this was love, I was misunderstood, mm (Song La La Lost You, line 25)

These lyrics conduct figurative language paradox. Niki thought that all pleasure she felt real happiness that was created for Niki, she expecting something good and fine, but not completely like that and it was run out so much of her expectation.

g. Allegory

I know (Song Lose, line 14)

We know better, so (Song Lose, line 15)

We'd both better go (Song Lose, line 16)

In the song above, Niki used figurative language allegory. Niki seems to make it as the whole storyline. it has principles and ideas of the song were explained in another form. Where does Niki mean, after all the difficulties she went through with the man in the song, she chose to separate because she thought it was the best for both of them.

2. The Contribution of This Study to Teaching Poetry

Chris B Brewer (1995) explains that using music for teaching media gave so many impacts, the impacts as follows:

1. Establish positive learning and desired atmosphere

2. Make learning full of attention and anticipation from the student and also from the teacher

3. Helping students absorb the material 
4. More focus on concentration while the study

5. Improving memory and enhance their imagination

6. Bringing a sense of community to a group

7. More inspiration and motivation while the study

8. More relaxing and make the learning more fun

The writer concluded that the contribution of this study toward teaching poetry is to help the students more interesting and easier to learn English especially in poetry studies. The writer also concluded that music (song lyrics) can make the students relax and open to learning identify the figurative language, and the last point is the learning and teaching activity using song lyrics creating a feeling and positive association of the learners.

\section{Conclusion}

Based on research findings and discussion in chapter IV the writer concluded that from the three songs entitled Lose, Indigo, and Lowkey, the writer found 41 expressions that contain figurative language. In the three songs, the writer found 7 types of figurative language that were used in the three songs they were metaphor, hyperbole, repetition, simile, apostrophe, paradox, and allegory. The writer does not find synecdoche, personification, and irony in the three songs.

The writer found that metaphor was the most dominant figurative language in the three songs. The writer found about 18 expressions that conduct figurative language metaphor. Then there was hyperbole with 9 expressions for the second dominant figurative language, repetition with 5 expressions for the third dominant figurative language, simile, and apostrophe about 3 expressions each figurative language were as the fourth dominant figurative language, paradox with 2 expressions as the fifth dominant figurative language, and the last dominant was allegory that only one expression from the three songs.

Besides the types and the dominant, the writer also elaborated some meaning of the song lyrics that conduct figurative language by paying attention to the meaning conveyed, watch the music video, and watched Niki's interview about the song on YouTube for more understand the meaning of the song. 
The first song entitled Lost is a very emotional love song that tells about disappointment. About a woman who is not loved by someone who is expected to love her back. In this song, Niki tells how she is stuck in a relationship that is not what she expected. The relationship that should give and take, while, their relationship is give-give and take-take. Niki is the one who always gives and gives to the man, giving her attention and love. While the man only accepts and accepts all that given by Niki to him without repaying the kindness that Niki has given. When Niki feels tired of such a relationship Niki decided to broke up and separate because that was the best option for them. So that no one else feels hurt again. in that song Niki used hyperbole more often because she wants to show the meaning of the song that she is very disappointed.

The second song entitled Indigo that tells about feelings of being attracted and falling in love, but wants to dominate. Like in the first part of the song's lyrics you know I'm your type, right? Mark your calendar, tonight's gonna be your life's highlight, Niki wanted to control the boys in the song. Niki played the role of a person who promises pleasure with sweet words, just like drugs that make users feel pleasure and addiction. Niki attracts many men with her sweet words so that many men approach her and eventually become addicted to Niki and controlled by her, like someone who was addicted to drugs. In that song, Niki used metaphor very often, she described her interest with unique words but still understood by the audience.

And the last one is a song entitled La La Lost You, this song was about farewell and how hard it is to move on, The song was telling a story about two people who have separated and tried to move on from each other. They were in Los Angles and New York but still thinking about each other until Niki finally found a better replacement, but her ex is still in a messy vase, like get the karma, trying found so many girls to replace Niki but he still remembers to Niki. In the song La La Lost You, Niki also used metaphors more often to describe her feelings in words that are easier to understand so that the meaning of the song conveyed properly.

\section{Reference}

Abrams, M.H. (1999). A Glossary Of Literary Terms (Revised Ed. 7). United States Of America: Earl Mcpeek. 
Akbary, M., Shahriari, H., \& Hosseini Fetemi, A. (2018). The Value Of Song Lyrics For Teaching And Learning English Phrasal Verbs: A Corpus Investigation Of Four Genres. Innovation In Language Learning And Teaching, 12 (4), 344-356.

Appen, R.V. And Frei-Hauenschild, M.(2015). Aaba, Refrain, Chorus, Bridge, Prechorus Song Forms And Their Historical Development. (Ver. 22.2). German Society For Popular Music Studies E. V.

Colston, Herbert L. 2015. Using Figurative Language. New York: Cambridge University Press.

Creswell, J.W. (2014). Research design: qualitative, quantitative, and mixed-method approaches (4th Edition). United States of America: Library of Congress Cataloging-inPublication Data. Sage.

Dews, S., \& Winner, E. (1995). Muting the Meaning: A Social Function Of Irony. Metaphor \& Symbolic Activity, 10(1), 3-19.

Eliot, T.S. (1942). The Music Of Poetry.Jackson, Son \& Company. The University of Glasgow. Jesús, Martínez Del Castillo. (2015). International Journal of Language And Linguistics Meaning. (Vol. 3). International Journal of Language And Linguistics.

Jones, S. (2002). Music That Moves Popular Music, Distribution And Technologies Cultural Studies, 16(2), 2013-232.

Kennedy, X.J. And Gioia. D. (2005). An Introduction to Poetry. (Ed. 11). United States: Longman

Keraf, Gory. (2006). Diksi Dan Gaya Bahasa (Ed. 16). Jakarta: PT. Gramedia Pustaka Utama.

Machosky, Brenda. (2010). Thinking Allegory Otherwise. Stanford, California. Stanford University Press.

Martinez, Jesus \& Martínez Del Castillo, Jesús. (2015). International Journal Of Language And Linguistics Meaning, What Is It. International Journal Of Language And Linguistics. 3. 67-76.

Nica, Marius. (2011). Teaching Poetry To Undergraduate Students: Social And Behavioral Science.

Ogilvie, John. (1970). An Essay On The Lyric Poetry Of The Ancients. Los Angeles. William Andrews Clark Memorial Library. University Of California.

Patel, A. D (2003). Language, Music, Syntax, and the Brain. Nature Neuroscience, 6(7), 674681.

Paxson, James J. (1994). The Poetics Of Personification. Cambridge University Press. 
Perloff, Marjorie, And Dworkin, Craig. (2009). the Sound Of Poetry. London: The University Of Chicago Press.

Piirto, Jane. (2011). Poetry. United States Of America: Elsevier Inc

Prinsky, Robert. (1999). The Sounds Of Poetry. The United States Of America. Douglas \& Mcintyre Ltd.

Sitorus, E. (2019). Learning Teaching: The Essential Guide To English Language Teaching. Macmillan Book For Teacher.

Sloboda, J. A., \& Caplow-Linnder, E. (2005). The Musical Mind: The Cognitive Psychology Of Music Program Director, Music Therapy Therapeutic Dance Movement: Expressive Activities For Older Adults Of Suffolk Child Development Center. Oxford University Press

Stanford Encyclopedia Of Philosophy (2017). Philosophy Of Music. Plato Stanford Education.

Stull, Bradford T. (1961). The Elements Of Figurative Language. New York: Pearson Education, Inc.

Swerman, Carla (2013). Figurative Language. Western Technical College Online Writing Center.

Virginia And Prins, Yopin. (2014). The Lyric Theory Reader A Critical Anthology. Baltimore. Johns Hopkins University Press

Weiss, Andrea L. (2006). Figurative Language in Biblical Prose Narrative. (Vol.107). Boston: Tuta Sub Aegide Pallas 1683.

Wellek, Rene. And Warren, Austin. (1980). Theory Of Literature. London. Great Britain By Lowe \& Brydone (Printers).

Woerther, F. (2008). Music And The Education Of The Soul In Plato And Aristotle: Homeopathy And The Formation Of Character. Classical Quarterly, 58(1), 89-103

Wordsworth, William, And T. Coleridge, Samuel. (1789). Lyrical Ballads. Bristol. British Library.

https://englishliterature.net/literary-devices/paradox

https://genius.com/88rising-and-niki-indigo-lyrics

https://genius.com/Niki-lose-lyrics

https://genius.com/Niki-lose-lyrics

Https://Seleb.Tempo.Co/Read/1061882/Niki-Penyanyi-Asal-Indonesia-Di-Industri-Musik-

Amerika-Serikat/Full\&View $=\mathrm{Ok}$

Https://Video.Tribunnews.Com/View/92432/Profil-Nicole-Zefanya-Penyanyi-Penulis-Lagu-

Dan-Produser-Rekaman 